\title{
Peningkatan Motivasi Dan Prestasi Belajar Matematika Dengan Menggunakan Media Styrofoam Kelas III SDN Tambakromo II Kecamatan Padas Kabupaten Ngawi
}

\author{
Djoko Hari Supriyanto, M.Pd ${ }^{1}$ \\ PGSD STKIP Modern Ngawi \\ djoko.hs@gmail.com \\ Arum Dwi Rahmawati, M.Pd ${ }^{2}$ \\ PGSD STKIP Modern Ngawi \\ arum.dr21@gmail.com
}

\begin{abstract}
Abstrak
Tujuan penelitian ini untuk mengetahui penggunaan media styrofoam dalam pembelajaran dapat mengalami peningkatan motivasi dan prestasi belajar Matematika dalam pokok bahasan pecahan sederhana kelas III SDN Tambakromo II Kecamatan Padas Kabupaten Ngawi.

Subjek penelitian ini adalah siswa kelas IV SDN Tambakromo II Kecamatan Padas Kabupaten Ngawi yang berjumlah 39 orang yang terdiri dari 25 siswa laki-laki dan 14 siswa perempuan. Pengumpulan data menggunakan pengamatan (observasi), angket (kuesioner) dan tes. Dalam penelitian ini menggunakan model Penelitian Tindakan Kelas (PTK) atau Class Action Research. Penelitian ini dilaksanakan di SDN Tambakromo II Kecamatan Padas Kabupaten Ngawi.

Dari penelitian tersebut didapat hasil yang menunjukkan adanya peningkatan motivasi belajar siswa terhadap pelajaran Matematika yaitu dari siklus I sebesar $72 \%$ menjadi $87 \%$ terdapat peningkatan sacara klasikal sebanyak $15 \%$. Prestasi belajar siswa secara klasikal meningkat sebanyak $13 \%$ dari siklus I sebesar $69 \%$ menjadi $82 \%$ pada siklus II. Keaktifan siswa secara klasikal mengalami peningkatan sebesar 7,6\% dari siklus I sebesar $69,3 \%$ menjadi $76,9 \%$ pada siklus II.

Berdasarkan hasil penelitian penggunaan media styrofoam mampu membuat siswa lebih memahami materi dengan cepat, tidak cepat bosan, dan melalui media styrofoam dapat mengalami peningkatan prestasi belajar pada pokok bahasan Pecahan sederhana Kelas III Semester II SDN Tambakromo II Kecamatan Padas Kabupaten Ngawi.
\end{abstract}

Kata kunci : Model Pembelajaran Kooperatif Tipe TPS. Prestasi Belajar.

\section{PENDAHULUAN}

Pengembangan sumber daya manusia merupakan inti dan titik berat dari pembangunan nasional secara keseluruhan. Keberhasilan pencapaian pembangunan nasional di masa yang akan datang akan sangat tergantung dari kualitas manusia yang dikembangkan pada masa kini. Sumber daya manusia di masa yang akan datang adalah anak-anak dan generasi muda pada masa kini. Hal ini berarti bahwa mempersiapkan dan membina anak-anak masa kini pada hakikatnya merupakan upaya mengembangkan sumber daya manusia bagi pembangunan di masa yang akan datang, salah satunya ditempuh melalui jalur pendidikan.

Kesulitan belajar matematika tidak hanya dialami oleh siswa di Indonesia tetapi juga dialami oleh siswa di berbagai negara (Soejadi, 2001).Sebagian besar siswa masih memandang matematika sebagai sebuah mata pelajaran dengan kumpulan rumus dan algoritma, karenanya dianggap sebagai mata pelajaran yang sangat sulit.

Sesuai dengan tujuan pendidikan nasional seperti yang tercantum dalam PP No. 19 Tahun 2005 (dalam Ibadullah Malawi, 2010) tentang Standar Nasional Pendidikan, pasal 26 disebutkan "Standar kompetensi 
lulusan pada jenjang pendidikan dasar bertujuan untuk meletakan dasar kecerdasan, pengetahuan, kepribadian, ahklak mulia, serta keterampilan untuk hidup mandiri dan mengikuti pendidikan lebih lanjut". Khusus untuk Sekolah Dasar tujuan pendidikan adalah memberikan bekal kemampuan dasar bacatulis-hitung, pengetahuan dan keterampilan dasar yang bermanfaat bagi siswa sesuai dengan tingkat perkembangan serta mempersiapkan mereka untuk mengikuti pendidikan di SMP.

Pada dasarnya permasalahan yang dihadapi di sekolah adalah minimnya sarana dan prasarana yang ada disekolah. Serta metode yang digunakan kurang efektif bagi siswa. Peranan guru dalam menentukan keberhasilan belajar siswa amat penting. Karena prestasi belajar siswa tidak saja dipengaruhi oleh kemampuan siswa dalam menerima pelajaran saja, akan tetapi juga dapat dipengaruhi oleh kemampuan gurunya yang mampu membangkitkan minat dan motivasi siswa pada saat diajar, maka sudah barang tentu akan sangat membantu siswa utuk dapat menerima pelajaran tersebut dengan sebaik-baiknya. Salah satu masalah pada jenjang sekolah dasar adalah masih ada pola pembelajaran yang kurang bervariasi dari guru. Selain itu kegiatan pembelajaran di kelas sering mengacu pada buku sehingga siswa kurang dapat mengaitkan materi pelajaran dengan lingkungan dan situasi dimana siswa berada. Oleh karena itu guru harus dapat memberikan pembelajaran yang efektif yaitu dengan cara menggunakan metodemetode atau media yang menarik. Dalam penggunaan metode atau media yang tidak membutuhkan biaya yang cukup banyak. Sebaiknya sekolah juga dapat mefasilitasi dalam hal sarana dan prasarana seperti media yang digunakan dalam setiap pembelajaran.

permasalan tersebut di atas sebenarnya ada satu masalah utama yang perlu mendapat perhatian, yaitu berkaitan dengan motivasi dan prestasi belajar pada pelajaran matematika. Sebagian besar siswa kurang termotivasi pada pelajaran matematika disebabkan guru yang masih menggunakan pembelajaran yang monoton. Bagi guru keberhasilan tersebut akan menimbulkan kepuasan, rasa percaya diri serta semangat mengajar yang tinggi. Hal ini berarti telah menunjukkan sebagian sikap guru professional yang dibutuhkan pada era globalisasi dengan berbagai kemajuannya, khususnya kemajuan ilmu dan teknologi yang berpengaruh pada pendidikan.

Upaya yang diperkirakan dapat meningkatkan motivasi siswa pada pelajaran Matematika adalah dengan menggunakan media Styrofoam. Sri Anitah (2008) Kata media berasal dari bahasa latin, yang merupakan bentuk jamak dari kata medium, yang berarti sesuatu yang terletak di tengah (antara dua pihak atau kutub) atau suatu alat. Oleh karena itu, media pembelajaran berarti sesuatu yang mengantarkan pesan pembelajaran antara pemberi pesan kepada penerima pesan.

Tujuan pembelajaran matematika adalah: 1) Melatih cara berpikir dan bernalar dalam menarik kesimpulan, misalnya melalui kegiatan penyelidikian, eksplorasi, eksperimen, menunjukkan kesamaan, perbedaan, konsisten dan inkonsistensi. 2) Mengembangkan aktivitas kreatif yang melibatkan imajinasi, intuisi, dan penemuan dengan mengembangkan pemikiran divergen, orisinil, rasa ingin tahu, membuat prediksi dan dugaan, serta mencoba-coba. 3) Mengembangkan kemampuan memecahkan masalah. 4) Mengembangkan kemampuan menyampaikan informasi atau mengkomunikasikan gagasan antara lain melalui pembicaraan lisan, grafik, peta, diagram, dalam menjelaskan gagasan.

Berdasarkan hasil data awal yang peneliti peroleh melalui kegiatan observasi dan wawancara kepada guru kelas III SDN Tambakromo II Kecamatan Padas Kabupaten Ngawi, Kecamatan Ngrambe dan pihak sekolah,diperoleh data hasil tes belajar siswa dengan kriteria sekitar $80 \%$ siswa mendapatkan nilai dibawah angka kriteria ketuntasan. Sehingga dapat dikatakan bahwa tingkat penguasaan siswa kelas III SDN Tambakromo II Kecamatan Padas Kabupaten Ngawi terhadap materi satuan pengukuran tersebut masih rendah. Hal tersebut disebabkan karena dalam 
proses pembelajaran guru hanya menggunakan metode ceramah dan belum menggunakan pembelajaran yang kooperatif.

Adapun rumusan masalah dalam penelitian ini yaitu 1) pakah penggunaan media Styrofoam dapat meningkatkan aktifitas dan prestasi belajar matematika pokok bahasan pecahan pada siswa kelas III SDN Tambakromo II Kecamatan Padas Kabupaten Ngawi? 2) Bagaimana peningkatan Motivasi dan prestasi belajar matematika dengan menggunakan media Styrofoam pokok bahasan pecahan pada siswa kelas III SDN Tambakromo II Kecamatan Padas Kabupaten Ngawi?

\section{METODE}

Jenis penelitian yang saya ambil adalah penelitian berupa Penelitian Tindakan kelas (PTK). Jenis penelitian ini mampu menawarkan cara dan prosedur baru untuk memperbaiki dan meningkatkan professionalisme pendidik dalam proses belajar mengajar di kelas dengan melihat kondisi siswa. Penelitian ini juga dapat menjebatani kesenjangan antara teori dan praktik pendidikan.

Dalam penelitian ini subyek penelitian dilakukan pada siswa tingkat SD yaitu pelaksanaan pembelajaran dilaksanakan terhadap siswa kelas III (tiga) semester II dengan jumlah siswa 39 anak yang terdiri dari 14 perempuan dan 25 laki-laki. Penelitian ini dilakukan dikelas III karena masih ada siswa yang kurang aktif dan kurang termotivasi dalam mengikuti pembelajaran Matematika. Peneliti juga ingin meningkatkan kemandirian siswa dalam menggunakan media Styrofoam sehingga siswa dapat mudah memahami materi yang diajarkan.

Teknik pengumpulan data yang digunakan dalam penelitian ini adalah observasi, angket dan tes.Teknik mengumpulkan data tersebut digunakan untuk memperoleh data sebagai bahan penyusunan penenlitian ini.

Wina Sanjaya (2009) menyatakan bahwa observasi merupakan teknik mengumpulkan data dengan cara mengamati setiap kejadian yang sedang berlangsung dan mencatatnya dengan alat observasi tentang halhal yang akan diamati atau diteliti.

Tes dilaksanakan setiap akhir siklus berupa tes formatif yang berguna untuk mengetahui hasil belajar siswa. Tes ini secara umum untuk mengetahui prestasi hasil belajar siswa dengan menggunakan media styrofoam pada siswa kelas III

Dalam penelitian ini data dari motivasi belajar siswa dalam pembelajaran Matematika yang diambil dengan menggunakan angket yang diisi oleh siswa. Instrumen berupa lembar tertutup dengan penilaian berbentuk skala Likert.

Analisa data disesuaikan dengan metode pengumpulannya. Analisis data merupakan proses menyeleksi, menyederhanakan, memfokuskan, mengabstraksikan data secara sistematis dan rasional untuk menyajikan bahan-bahan yang dapat digunakan untuk menyusun jawaban masalah yang menjadi tujuan penelitian tindakan kelas.

\section{HASIL DAN PEMBAHASAN \\ Deskripsi Hasil Penelitian}

Penelitian ini dilaksanakan dalam dua siklus, masing-masing siklus terdiri dari empat tahap yaitu tahap perencanaan (planning), tahap pelaksanaan (acting), tahap pengamatan (observing), dan tahap refleksi (reflecting).

\section{Siklus 1}

\section{Tahap Perencanaan (Planning)}

Pada tahap ini dilakukan penentuan materi dan tujuan pembelajaran yang akan disampaikan pada siswa. Materi yang akan diajarkan yaitu tentang pecahan sederhana. Sebelum pelaksanaan pembelajaran, peneliti menyusun instrumen-instrumen yang diperlukan diantaranya silabus, rencana pelaksanaan pembelajaran, lembar angket motivasi belajar siswa, lembar soal untuk setiap kelompok diskusi belajar, menyusun lembar evaluasi, dan lembar observasi aktivitas siswa

Tahap Pelaksanaan Tindakan (Acting) 
Pada tahap ini dilaksanakan dengan alokasi waktu 2 x 35 menit dan kegiatan yang dilaksanakan meliputi semua tindakan yang telah direncanakan pada siklus I.

\section{Tahap Pengamatan (Observing)}

Pada penilaian aktivitas siswa terdapat 3 aspek nilai yang meliputi keberanian siswa dalam menyampaikan pendapat, kecepatan mengerjakan soal dan perhatian siswa dalam pembelajaran.

Tabel Frekuensi Pencapaian Kriteria Aktivitas Belajar Siswa Siklus I

\begin{tabular}{|c|c|c|c|}
\hline Nilai & Frekuensi & $\begin{array}{l}\text { Presentase } \\
(\%)\end{array}$ & Indikator \\
\hline $85-100$ & 9 & 23 & Sangat \\
\hline $70-84$ & 18 & 46 & Aktif \\
\hline $55-69$ & 9 & 23 & Cukup \\
\hline $40-54$ & 3 & 7,7 & Kurang \\
\hline $0-39$ & 0 & 0 & Sangat \\
\hline & & & Kurang \\
\hline Jumlah & 39 & $100 \%$ & \\
\hline \multicolumn{4}{|c|}{$\begin{array}{l}\text { Indikator ketercapaiannya aktivitas belajar } \\
\text { siswa } \geq 70 \text { (aktif) }\end{array}$} \\
\hline \multicolumn{4}{|c|}{ Ketuntasan klasikalnya $75 \%$} \\
\hline
\end{tabular}

Dari tabel dapat diketahui frekuensi siswa yang mencapai kriteria aktif dan sangat aktif sebanyak 27 siswa atau 69,3\% dari seluruh siswa, hasil ini belum mencakup ketercapaiannya klasikal yaitu $75 \%$.

Ketuntasan belajar siswa dapat diketahui dengan melakukan tes diakhiri kegiatan pembelajaran.

Tabel Hasil dari ketuntasan belajar pada siklus I

\begin{tabular}{|l|c|c|c|}
\hline SKM & Frekuensi & $\begin{array}{c}\text { Presentasi } \\
(\%)\end{array}$ & Keterangan \\
\hline$\geq 70$ & 27 & 69 & Tuntas \\
$<70$ & 12 & 31 & Belum \\
& & Tuntas \\
& & \\
\hline Indikator ketercapaiannya hasil belajar $\geq$ \\
65 \\
Ketuntasan klasikalnya $75 \%$ \\
\hline
\end{tabular}

Diketahui bahwa siswa yang memperoleh nilai lebih dari atau sama dengan 65 sebanyak 27 siswa, berarti $69 \%$ dari seluruh jumlah siswa yaitu 39 siswa sudah mencapai Standar Ketuntasan Minimal (SKM). Secara klasikal hasil belajar siswa pada siklus I belum mencapai indikator yang ditentukan yaitu $75 \%$.

Hasil dari angket yang dibagikan pada siklus I diketahui frekuensi siswa yang mencapai kriteria baik dan sangat baik sebanyak 28 siswa atau $72 \%$ dari seluruh siswa, hasil ini belum mencapai indikator yang ditentukan yaitu $75 \%$.

Tabel Frekuensi Pencapaian Kriteria Motivasi Belajar Siswa Siklus I

\begin{tabular}{|c|c|c|l|}
\hline Nilai & Frekuensi & Presentase & Indikator \\
\hline $85-100$ & 6 & 16 & Sangat \\
$70-84$ & 22 & 56 & baik \\
$55-69$ & 11 & 28 & Baik \\
$40-54$ & 0 & 0 & Cukup \\
$0-39$ & 0 & 0 & Kurang \\
& & Sangat \\
& 39 & $100 \%$ & Kurang \\
\hline Jumlah & 39 & \\
\hline Indikator ketercapaiannya motivasi belajar \\
siswa $\geq 70$ (baik) \\
Ketuntasan klasikalnya $75 \%$ \\
\hline
\end{tabular}

\section{Tahap Refleksi (Reflecting)}

Hasil refleksi dari kegiatan pembelajaran dapat diketahui bahwa motivasi dan prestasi belajar siswa belum mencapai indikator yang ditetapkan, aktivitas siswa dan guru belum mencapai indikator yang ditetapkan

\section{Siklus 2}

\section{Tahap Perencanaan (Planning)}

Pada tahap ini dilakukan penentuan materi dan tujuan pembelajaran yang akan disampaikan pada siswa. Materi yang akan diajarkan yaitu tentang pecahan sederhana. Sebelum pelaksanaan pembelajaran, peneliti menyusun instrumen-instrumen yang diperlukan diantaranya silabus, rencana pelaksanaan pembelajaran, lembar angket motivasi belajar siswa, lembar soal untuk setiap kelompok diskusi belajar, menyusun lembar evaluasi, dan lembar observasi aktivitas siswa.

Tahap Pelaksanaan Tindakan (Acting) 
dalam pembelajaran untuk meningkatkan motivasi belajar siswa agar proses pembelajaran dapat mencapai hasil yang optimal sesuai yang ditetapkan.

Berdasrakan hasil penelitian dapat diketahui adanaya peningkatan motivasi belajar siswa, prestasi belajar siswa dan aktivitas siswa. keaktifan siswa diperoleh dari observasi pada waktu kegiatan pembelajaran berlangsung, indicator yang diharapkan jika $\geq 75 \%$ keseluruhan siswa dapat nilai $\geq 70$ (baik). Dari hasil observasi menunjukkan adanya peningkatan keaktifan siswa dari silus I ke siklus II.

\begin{tabular}{|c|c|c|c|c|c|}
\hline \multirow[b]{2}{*}{ Data } & \multicolumn{2}{|c|}{ Siklus I } & \multicolumn{2}{|c|}{ Siklus II } & \multirow[b]{2}{*}{$\begin{array}{c}\text { Penin } \\
\text { gkatan } \\
(\%)\end{array}$} \\
\hline & $\begin{array}{l}\text { Frekue } \\
\text { nsi }\end{array}$ & $\begin{array}{l}\text { Prens } \\
\text { entas } \\
\text { e }\end{array}$ & $\begin{array}{l}\text { Fre } \\
\text { kue } \\
\text { nsi }\end{array}$ & $\begin{array}{l}\text { Pres } \\
\text { enta } \\
\text { se }\end{array}$ & \\
\hline $\begin{array}{l}\sum \\
\text { siswa } \\
\text { yang } \\
\text { mem } \\
\text { punya } \\
\text { i } \\
\text { keakti } \\
\text { fan } \\
\text { aktif } \\
\text { dan } \\
\text { sanga } \\
\text { t aktif }\end{array}$ & 27 & 69,3 & 30 & 76,9 & $7,6 \%$ \\
\hline
\end{tabular}

Peningkatan aktivitas ini dapat terlihat ketika siswa sedang mendiskusikan soal yang diberikan guru. Dengan penggunaan media styrofoam aktivas siswa dapat meningkat karena siswa diberi kesempatan untuk berinteraksi secara aktif dengan temannya. Siswa tidak hanya diam mendengarkan materi yang disampaikan guru, tetapi juga mempelajari kembali bersama dengan temannya.

Data prestasi belajar siswa diperoleh dari tes tertulis yang berbentuk isian yang telah dikerjakan setelah proses pembelajaran berlangsung. Indikator yang diharapkan jika $75 \%$ keseluruha siswa mendpat nilai minimal $\geq$ 70. Dari hasil penelitian yang dilakukan menunjukkan adanya peningkatan prestasi belajar dari siklus I ke siklus II, yang telha tercapai ketuntasan minimal, sehingga terdapat peningkatan jumlah siswa yang tuntas belajar $13 \%$. Data hasil analisis tersebut dapat dilihat dalam tabel

\begin{tabular}{|c|c|c|c|c|c|}
\hline \multirow[b]{2}{*}{ SKM } & \multicolumn{2}{|c|}{ Siklus I } & \multicolumn{2}{|c|}{ Siklus II } & \multirow{2}{*}{$\begin{array}{l}\text { Peni } \\
\text { ngka } \\
\text { tan }\end{array}$} \\
\hline & $\begin{array}{c}\text { Frek } \\
\text { uens } \\
\text { i }\end{array}$ & $\begin{array}{l}\text { Prese } \\
\text { ntase }\end{array}$ & $\begin{array}{c}\text { Freku } \\
\text { ensi }\end{array}$ & $\begin{array}{c}\text { Presen } \\
\text { tase }\end{array}$ & \\
\hline$\geq 70$ & 27 & 69 & 32 & 82 & \multirow{2}{*}{$13 \%$} \\
\hline$<70$ & 12 & 31 & 7 & 18 & \\
\hline Indica & eter & an & al 7 & & \\
\hline
\end{tabular}

Peningkatan prestasi belajar siswa. peningkatan prestasi belajar siswa terlihat pada hasil evaluasi siswa. Pada saat mengajukan soal evaluais bayak jawaban siswa yang benar

Prestasi belajar siswa meningkat karena dengan diterapkannya media styrofoam, siswa dapat lebih memahami materi. Siswa tidak hanya menerima materi yang disampaikan guru, tetapi mereka juga mengingatnya kembali dengan temannya dalam suasana yang menyenangkan. Mereka dapat belajar sambil bermain. Dengan mengulang kembali materi yng telah dipelajari maka ingatan siswa terhadap materi lebih kuat.

Data motivasi belajar siswa diperoleh dari angket yang berbentuk skala Likert yang dikerjakan setelah proses pembelajaran berlangsung. Indicator yang diharapkan jika $75 \%$ keseluruhan siswa mendapat nilai $\geq 70$.

Dari hasil penelitian yag dilakukan menunjukkan adanya peningkatan prestasi belajar siswa dari siklus I ke siklus II yaitu sebesar 15\%. Data hasil analisis tersebut dapat dilihat dalam table dibawah ini :

\begin{tabular}{|c|c|c|c|c|c|}
\hline \multirow{2}{*}{$\begin{array}{c}\text { Data yang } \\
\text { diperoleh }\end{array}$} & \multicolumn{2}{|c|}{$\begin{array}{c}\text { Siklus } \\
\text { I }\end{array}$} & \multicolumn{2}{|c|}{$\begin{array}{c}\text { Siklus } \\
\text { II }\end{array}$} & \multirow{2}{*}{$\begin{array}{c}\text { Peningkatan } \\
(\%)\end{array}$} \\
\hline & $\Sigma$ & $\%$ & $\sum$ & $\%$ & \\
\hline $\begin{array}{l}\sum \text { siswa } \\
\text { yang } \\
\text { mempunyai } \\
\text { motivasi } \\
\text { baik dan } \\
\text { sangat baik }\end{array}$ & 28 & 72 & 34 & 87 & 15 \\
\hline
\end{tabular}


Peningkatan motivasi belajar siswa terlihat pada antusiasme siswa pada saat mengikuti pelajaran. Siswa dengan sugguhsungguh memperhatikan materi yang disampaiakan guru dan memberikn respon aktif ketika perwakilan dari kelompok lain membacakan hasil diskusinya.

Peningkatan motivasi belajar siswa terjadi karena siswa senang dengan penggunaan media styrofoam yang dapat diwarnai sesuai keinginan siswa.

\section{SIMPULAN}

Berdasarkan hasil penelitian mengenai pembelajaran dengan menggunakan media styrofoam sebagai salah satu upaya untuk meningkatkan motivasi dan prestasi belajar matematika kelas III SDN Tambakromo II Kecamatan Padas Kabupaten Ngawi. Penggunaan media styrofoam mampu meningkatkan aktifitas dan prestasi belajar siswa, khususnya pada pokok bahasan pecahan sederhana. Hasil aktivitas belajar siswa menunjukkan Siklus I 69,3\% dan pada siklus II meningkat menjadi 7,6\%. Peningkatan motivasi dan prestasi belajar matematika pokok bahasan pecahan dengan dilakukannya tes pada siswa kelas III yang meningkat secara signifikan. Hal ini ditunjukkan pada hasil angket menunjukkan bahwa motivasi belajar siswa pada siklus I baru mencapai $72 \%$ dan pada siklus II menjadi $87 \%$. Jadi peningkatan motivasi belajar ini sebesar $15 \%$. Sedangkan pada prestasi belajar siklus I ketuntasan belajar siswa baru mencapai $69 \%$ dan pada siklus II meningkat menjadi $72 \%$. Jadi peningkatan siklus I ke siklus II sebesar 13\%.

\section{SARAN}

Dalam melaksanakan proses belajar mengajar, guru hendaknya perlu melakukan beberapa hal, yaitu: a) Guru harus mampu menciptakan suasana pembelajaran yang menyenangkan sehingga siswa tidak merasa bosan. b) Guru harus mampu menerapkan metode atau model pembelajaran yang sesuai dengan materi yang disampaikan kepada siswa. c) Guru harus senantiasa memotivasi siswa dengan berbagai cara guna meningkatkan prestasi belajar siswa.

Penerapan menggunakan media styrofoam akan membantu siswa dalam memahami materi pelajaran matematika, meningkatakan motivasi, dan prestasi belajar siswa.

Kepala sekolah selaku penanggungjawab sekolah perlu melakukan beberapa hal yaitu: a) Memberikan dorongan kepada para guru untuk lebih aktif dan kreatif dalam mengadakan inovasi pembelajaran. b) Memfasilitasi para guru untuk mengembangkan kreatifitas mereka demi mendukung kemajuan serta keberhasilan pembelajaran. c) Mengadakan sharing dengan para guru tentang hambatan-hambatan yang ditemui dalam pembelajaran di kelas.

\section{DAFTAR PUSTAKA}

Adi Yasa., I Made, I Wayan Sadra, Gede Suweken. (2013). Pengaruh Pendidikan Matematika Realistik dan Gaya Kognitif Terhadap Prestasi Belajar Matematika Arini Math.Blockspot.com.14 feb 2008.Definisi-matematika, 20 Maret 2011.

Akmad Sudrajat.blogspot.com.03 Nov 2008. Media Pembelajaran, 18 juli 2011.

Baharuddin, Esa Nur Wahyunu. (2007). Teori Belajar dan Pembelajaran.Jogjakarta : Ar-Ruzz Media.

Djaali. (2007). Psikologi Pendidikan.Jakarta: Bumi Aksara.

Hamid Darmadi. (2010). Kemampuan Dasar Mengajar.Bandung: Alfabeta.

Hamzah B.Uno. (2007). Model Pembelajaran.Jakarta : Bumi Aksara.

Nana Sudjana,Ahmad Rivai. (2002). Media Pembelajaran.Bandung: Sinar Baru Algensindo.

Sardiman. (2001). Interaksi dan Motivasi Belajar Mengajar.Jakarta : PT Raja Grafindo Persada. 
Slameto. (2010). Belajar dan faktor-faktor yang mempengaruhinya.Jakarta: Rineka Cipta.

Sri Anitah. (2008). Media Pembelajaran.Surakarta : UNS Press.

Suharsimi Arikunto, Suhardjono, Supardi. (2006). Penelitian Tindakan Kelas.Jakarta : Bumi Aksara

Suharsimi Arikunto. (2002). Prosedur Penelitian Suatu Pendekatan Praktik.Jakarta : Rineka Cipta.

Supri wahyudi, Satridjo Budi Wibowo. (2007). Jurnal Pendidikan. IKIP PGRI MADIUN.

Syaiful Bahri Djamarah. (2002). Psikologi Pembelajaran.Jakarta : Rineka Cipta.

Silberman, Melvin. (2006). Active Learning 101 Cara Belajar Siswa Aktif. Bandung: Nusamedia.

Sugiyono. (2008). Statistika Untuk Penelitian. Bandung: CV Alfabeta.

Suharsimi, Arikunto. (2005). Manajemen Penelitian. Jakarta: PT Rineka Cipta.
(2006). Prosedur

Penelitian Suatu Pendekatan Praktik. Jakarta: PT Rineka Cipta.

Suroso. (2005). Perbedaan Prestasi Belajar Matematika Siswa Yang

Pembelajarannya Menggunakan Media Komputer Dengan Yang Tidak Menggunakan Media Komputer Siswa Kelas 2 Di SMP Negeri 1 Wungu. IKIP PGRI Madiun.

Tanwey Gerson Ratumanan. (2002). Belajar dan Pembelajaran.Unesa University Press.

Wina Sanjaya. (2006). Pembelajaran Implementasi Kurikulum berbasis Kompetensi. Jakarta : Kencana Prenada Media Group.

(2009). Kurikulum dan Pembelajaran.Jakarta Kencana Prenada Media Group.

Id.wikipedia.org.08 Sep 2010. Gabus.20 Maret 2011. 